\title{
The Existence of Women's Roles during the COVID-19 Pandemic: A Case Study of 3 Women in Yogyakarta
}

\section{Napsiah *, (D), Ahmad Norma Permata $\left(\mathbb{D}\right.$, Dwi Nur Laela Fithriya $\mathbb{D}^{\mathbb{D}}$, and Hikmalisa}

Department of Sociology, Faculty of Social Sciences and Humanities, Universitas Islam Negeri Sunan Kalijaga, 55281, Yogyakarta, Indonesia

*Corresponding Author: napsiah@uin-suka.ac.id

\begin{tabular}{l}
\hline ARTICLE INFO \\
\hline $\begin{array}{l}\text { Publication Info: } \\
\text { Research Article }\end{array}$
\end{tabular}

How to cite:

Napsiah, N., Permata, A. N., Fithriya, D. N. L., \& Hikmalisa, H. (2021). The Existence of Women's Roles during the COVID-19 Pandemic: A Case Study of 3 Women in Yogyakarta. Society, 9(2), 477-489.

DOI: $10.33019 /$ society.v9i2.326

Copyright (C) 2021. Owned by Author(s), published by Society

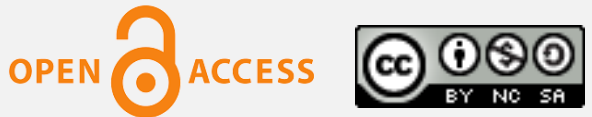

This is an open-access article.

License: AttributionNonCommercial-ShareAlike (CC BY-NC-SA)

\begin{abstract}
The COVID-19 pandemic has erased the stereotype of the domestication of women with the status of women as housewives and career women, which has an impact on women's double burden, namely doing domestic work and public work. This article aims to prove that the domestic sector has strengthened the existence of women. This research is descriptive qualitative by interviewing three career women in Yogyakarta. They were selected by direct pointing because these women can provide relevant information in this study. Indirect observations were carried out to explore information that was not conveyed at the time of the interview. Information from journals, websites, and newspapers was used to strengthen the data. The results showed that women's ability to manage the household had an effect during the COVID-19 pandemic, namely the Work From Home (WFH) policy. Women's domestic roles include women's managerial abilities in utilizing home facilities such as the living room, family room, workspace, and even the kitchen room and mastery of home facilities such as Wi-Fi, laptops, and cellphones used by other family members. It also provides ample opportunity for women to demonstrate their ability to carry out domestic sector jobs such as cooking, protecting family members, and doing public work such as seminars, teaching, selling services, business, and forming social groups to help disaster victims. In line with that, the role of women in the domestic sector and public sector is balanced, thereby strengthening women's existence during the COVID-19 pandemic.
\end{abstract}


Received: March 28, 2021;

Accepted: June 29, 2021;

Published: December 31, 2021;
Keywords: COVID-19; Domestic; Stereotypes; Women's Existence

\section{Introduction}

The COVID-19 disaster for women is like two sides of a coin. On the one hand, COVID-19, with the Work From Home (WFH) policy, has caused gender inequality due to termination of employment where companies close, which affect women's impoverishment, women are subordinated, a double burden for completing domestic work and public work, as well as domestic violence due to home quarantine (Halaris, 2003; Leung et al., 2020; Kristal \& Yaish, 2020; Casale \& Posel, 2021). Therefore, COVID-19 has caused inequality. Shamseer et al. (2021) even indicated that the COVID-19 pandemic over the past two years had erased gender equality which had been fought for 25 years. However, on the other hand, the COVID-19 pandemic strengthened gender equality because of Work from Home (WFH). Women with domestic stereotypes have shown that the domestic sector plays a major role in supporting public work. The ability to manage the household and control over space and ownership of facilities at home have led them to become workers who can complete domestic work and public work in a balanced way and have the ability to express themselves through the patriarchal culture that requires women to only stay at home and do domestic work. Even if women work in the public sector, the work adds to their burden. However, the stereotype has undergone a shift. Domestic space has led women to actualize themselves by building broad social relations and contributing to the wider community.

So far, research on the impact of the pandemic on women can be categorized into the following themes: first, research on the role of women in education during COVID-19 (Khan et al., 2021). The research shows that women experience the burden of double because women do domestic work and at the same time become teachers for school-age children. Second is the impoverishment of women due to termination of employment and insufficient husband's income (Zamberlan et al., 2021; Casale \& Posel, 2021; Sulistyawati et al., 2021). As a result of the limited funds obtained, women seek additional income by working online, which takes up a lot of time. Third, violence is increasing (Raj et al., 2020; Susiana, 2020; Halaris, 2003; Londoño et al., 2021; Sulaeman \& Salsabila, 2020; Leung et al., 2020; Shammi et al., 2020) because the quarantine period has left women home, so violence often occurs. Research has shown that the COVID-19 pandemic has worsened the position of women, not only the process of marginalization, subordination of double burdens, and violence against women.

Meanwhile, the stereotype of women's domestication has become a factor that has been taken into account in the COVID-19 pandemic because of the Social Distancing policy. All workers in the public sector, including school children, have been sent home or known as Work From Home. Not many have studied it. Therefore, this study complements the studies above. Accordingly, this research is important to do.

The purpose of this study is to prove that the COVID-19 period has strengthened gender equality because women's self-actualization has been proven by the ability to manage domestic work and household work does not cause gender inequality. Accordingly, three questions were asked: first, identify domestic and public work?. Second, why can women manage these two big tasks at home? Third, what is the impact of women's ability to manage the domestic and public sectors? 
This research argues that COVID-19 with the Work from Home (WFH) policy impacts "returning" jobs in the public sector to the domestic sector, not adding to the burden on women. Second, public work and domestic work are two jobs that are done in a balanced way. Third, public work and domestic work done at home have strengthened the existence of women.

\section{Literature Review}

\subsection{COVID-19}

COVID-19 has caused unrest in various countries and has brought back memories of the outbreak that occurred in 1918 (Wan et al., 2020; Jiang et al., 2021). The COVID-19 outbreak is similar to respiratory syndrome disease with a high risk of death (Huang et al., 2020). Such is the case in Vietnam, where the country has mobilized the entire political system to fight the COVID-19 pandemic and achieved some initial successes. However, the situation still shows complexity in handling (Hoang et al., 2020). The COVID-19 outbreak has had an impact on the economy (Nasution et al., 2020; Yamali \& Putri, 2020; Hadiwardoyo, 2020; Rahmadia \& Febriyani, 2020; Hanoatubun, 2020). COVID-19 also impacts the education system from face-toface to online (Dewi, 2020; Syah, 2020; Siahaan, 2020). COVID-19 has also changed work patterns from working outside the home to working from home.

The Indonesian government has implemented policies dealing with the COVID-19 outbreak, such as Large-Scale Social Restrictions (Ristyawati, 2020; Nasruddin \& Haq, 2020; Herdiana, 2020; Saputra \& Salma, 2020; Fathoni, 2019). These policies have an impact on community activities. Work done at home causes people to go into culture shock. Early marriage has occurred due to online learning. Although early marriage can be prevented, it occurs in various areas. Even a report from the Bandung ministry has reported that early marriage is increasing. Cases experienced by women regarding violence also occur. This can be seen in studies (Casale \& Posel, 2021; Susiana, 2020), which say domestic violence occurs due to COVID-19. But here, COVID-19 shows that women are stronger immune than men because they wash their hands more often. Thus, the mortality rate of women is lower than that of men. In addition, women also find it easier to recover because work in the domestic sector has made them eat better food. In line with that, women in the COVID-19 era have positive and negative impacts. On the one hand, they have marginalized women. On the other hand, COVID-19 has formed women who are responsive to disasters to have the resilience to COVID-19 (Jacob et al., 2020; Chang, 2020).

\subsection{Women and the COVID-19 Disaster}

Women are considered vulnerable in dealing with disasters (Jacob et al., 2020; Rana et al., 2021). The disaster has made women's conditions worse, such as violence in the refugee camps. There are no gender-sensitive refugee barracks or clean water to infect various diseases. The study (Kristal \& Yaish, 2020) also stated that women experience vulnerability in humanitarian disasters because they are trafficked and contract marriages and prostitution. Thus, a disaster for women is a condition that is not "friendly" to women.

But on the other hand, women have high resilience. Women's resilience in disasters is influenced by the physical condition of women in fighting pain such as pregnancy, childbirth, and breastfeeding (Leung et al., 2020; Chang, 2020). The stereotype also influences resilience to disasters in society that women are weak and therefore vulnerable to disasters. These two 
causes are used to be felt by women so that there is a strength that has been felt and will be expressed during disaster conditions so that women have high resilience to disasters.

The resilience of women to disasters is their ability to rise from disasters, even in limited conditions. Still, women can take real actions to organize a normal life again quickly. The ability to manage existing resources for economic gain, organize, and take action is an indicator that proves they are resilient to disasters (Shammi et al., 2020; Chang, 2020).

\subsection{Domestic Stereotypes to the Existence of Women in the COVID-19 Pandemic}

Women's ability to manage homes impacts women's ability to respond to social distancing policies, physical distancing and, at the same time, has shown the existence of women. Initially, identical domestic jobs did not produce financial results. They were considered not prestigious jobs, so women who worked in the domestic sector were not in demand by women, causing gender inequality (Zamberlan et al., 2021). In line with that, opening job opportunities and accessing technology opens up women's opportunities to enter the public sector. The very diverse goals are not only for economic gain but also for the existence of women (Zamberlan et al., 2021).

The government implemented the Work From Home (WFH) policy to anticipate the transmission of COVID-19 affects public activities. Thus, the policy has an impact on public activities. Initially, public activities were carried out outside the home with the duration of time determined by the government and company agencies at work. However, since the enactment of the policy, public activities have been "laid off" without reducing productivity.

In this regard, the house becomes a place of production that is expected to generate an economy. From home, they complete work that generates economic value and social value. The relationship between husband and wife and children is not far apart because even though their work is limited by a room dividing wall, in that house, they can establish intense communication and the role of a woman becomes a leader at home (Sulaeman \& Salsabila, 2020). Women have mastered arenas at home that previously did not function to run jobs in the public sector that generate the economy.

During the COVID-19 pandemic, the Work From Home (WFH) policy impacted the world of women. The term domestication of women has had a significant impact. Women show important roles in terms of work at home and being leaders at home. They establish social relations with family members, friends, and the wider community from home. They formed a union to form social groups that cared about their fellow COVID-19 victims. Through cell phones, the network is connected to women throughout the archipelago.

Action to care for disaster victims is one of the actions taken by women. This action aims to form awareness by assisting in necessities and other necessities to relieve the COVID-19 disaster and flood victims. In addition, the action to conduct seminars with relevant programs has become an action taken by women during COVID-19.

\section{Research Methodology}

Research on women's role in the COVID-19 pandemic has been studied on gender studies. However, the study of these experts concluded that the COVID-19 pandemic period with the Work From Home Policy added to the double burden of women, so gender equality did not work. Research on women's existence has strengthened since the COVID-19 outbreak. Because of WFH policy, the role of women in the domestic sector and the public sector carried out at home does not add to the double burden of women because women can carry out both roles in 
a balanced way and produce broad social relations. To find this evidence, this descriptive qualitative research interviewed three women who work in higher education (lecturers), entrepreneurs, and laborers who live in Yogyakarta. Women who work in the public sector are selected, and information is explored because career women are considered by society to only add to the workload. After all, domestic work is an inseparable job, while public work, which has its binding and formal system, requires the active involvement of women. Interview data were also strengthened by making indirect observations to see the activities of the three women, which could not be revealed through interviews. Secondary data obtained from journals, books, and newspapers are used to support the information needed in this article. Although the Work From Home (WFH) policy will still last until August 2021, it is unknown when it will end. However, data collection has been carried out since the implementation of the Work From Home Policy, namely April 2020, and is limited to February 2021. Data analysis is carried out by reducing the beginning, drawing conclusions, and presenting them in tables and meaningful narratives.

\section{Results and Discussion}

\subsection{The Balance between Public Work and Domestic Sector}

Women in the public sector carry out their routine duties in the office according to their working hours, from $7.30 \mathrm{am}$ to $4.00 \mathrm{pm}$. All work is done in offices such as on-campus for women who are lecturers, batik shops for batik workers, and industry for industrial workers. Their routines are adapted to their respective fields of work. Because the work is carried out in the office, the home is separate from public work. However, in the COVID-19 era, homes have become offices. The house is an office center, a place for educational institutions, and a house is also a place for the production of domestic work. Thus, the house becomes a place of productivity for women's activities in carrying out public and domestic tasks, as shown in Table 1. The house is a multifunctional place in the COVID-19 pandemic era to complete both tasks.

Table 1. Public and Domestic Work done at Home

\begin{tabular}{|c|l|l|l|}
\hline \multirow{2}{*}{ Informant } & \multicolumn{1}{|c|}{ Public Work } & \multicolumn{2}{|c|}{ Domestic Work } \\
\hline Profession & \multicolumn{1}{|c|}{ Main Task } & \multicolumn{1}{|c|}{ Duty to Children } & \multicolumn{1}{c|}{ Housework } \\
\hline \multirow{4}{*}{ Lecturer } & Teaching online & $\begin{array}{l}\text { Monitor children online, make } \\
\text { sure they are signed in to } \\
\text { Zoom Meetings or Google } \\
\text { Classroom, and attendance }\end{array}$ & $\begin{array}{l}\text { Preparing family } \\
\text { breakfast }\end{array}$ \\
\cline { 2 - 5 } & Discussion & Operate work equipment & Cook \\
\cline { 2 - 5 } & Seminar & Ensuring children's attendance & Wash \\
\cline { 2 - 5 } & Test students & Monitor children's work & Provide snacks \\
\cline { 2 - 5 } & $\begin{array}{l}\text { Thesis/thesis } \\
\text { proposal seminar }\end{array}$ & $\begin{array}{l}\text { Monitoring on children's work } \\
\text { results }\end{array}$ & $\begin{array}{l}\text { Provide food stock in } \\
\text { the refrigerator }\end{array}$ \\
\cline { 2 - 5 } & Work meeting & $\begin{array}{l}\text { Meetings with teachers about } \\
\text { Distance Learning }\end{array}$ & To the market \\
\hline
\end{tabular}

Copyright (C) 2021. Owned by Author(s), published by Society. This is an open-access article under the CC-BY-NC-SA license. 
The Existence of Women's Roles during the COVID-19 Pandemic:

A Case Study of 3 Women in Yogyakarta

\begin{tabular}{|c|c|c|c|}
\hline Informant & Public Work & \multicolumn{2}{|c|}{ Domestic Work } \\
\hline \multirow[t]{2}{*}{ Profession } & Main Task & Duty to Children & Housework \\
\hline & $\begin{array}{l}\text { Serving the } \\
\text { community }\end{array}$ & $\begin{array}{l}\text { Attend meetings with tutoring } \\
\text { institutions }\end{array}$ & Cleaning the house \\
\hline \multirow{8}{*}{$\begin{array}{c}\text { Batik } \\
\text { Entrepreneur }\end{array}$} & $\begin{array}{l}\text { Shop open in a short } \\
\text { time }\end{array}$ & Parents meeting at school & Cook \\
\hline & $\begin{array}{l}\text { Sales via online and } \\
\text { offline }\end{array}$ & Meeting with fellow parents & To the market \\
\hline & $\begin{array}{l}\text { The salary of } 10 \\
\text { employees is still } \\
\text { given }\end{array}$ & $\begin{array}{l}\text { Discussion about the } \\
\text { development of children's } \\
\text { achievements }\end{array}$ & $\begin{array}{l}\text { Cleaning the house } \\
\text { because the maid } \\
\text { didn't come }\end{array}$ \\
\hline & $\begin{array}{l}\text { There are additional } \\
\text { items }\end{array}$ & $\begin{array}{l}\text { Monitoring the progress of } \\
\text { reading the Quran }\end{array}$ & Wash \\
\hline & $\begin{array}{l}\text { Relationships with } \\
\text { batik suppliers are } \\
\text { established via } \\
\text { online }\end{array}$ & Monitoring children online & Ironing \\
\hline & $\begin{array}{l}\text { Expenditures on } \\
\text { shop rental and } \\
\text { electricity and water } \\
\text { are reduced, but } \\
\text { quotas are } \\
\text { increasing }\end{array}$ & $\begin{array}{l}\text { Provide two laptops for Zoom } \\
\text { Meeting }\end{array}$ & $\begin{array}{l}\text { Prepare breakfast, } \\
\text { lunch, and family } \\
\text { dinner }\end{array}$ \\
\hline & Still have income & $\begin{array}{l}\text { Help back up data because the } \\
\text { signal is often not supported }\end{array}$ & \\
\hline & & Helping children's schoolwork & \\
\hline \multirow{4}{*}{ Laborer } & $\begin{array}{l}\text { Not working in a } \\
\text { factory during the } \\
\text { COVID-19 } \\
\text { pandemic but } \\
\text { working and } \\
\text { cooking for a } \\
\text { Padang restaurant }\end{array}$ & $\begin{array}{l}\text { Children online: Zoom } \\
\text { Meeting/Google Classroom }\end{array}$ & To the market \\
\hline & $\begin{array}{l}\text { Help with the } \\
\text { ironing at the } \\
\text { neighbor's laundry }\end{array}$ & Checking the learning process & Cook \\
\hline & $\begin{array}{l}\text { There is income } \\
\text { from working } \\
\text { cooking }\end{array}$ & $\begin{array}{l}\text { Join a meeting via Zoom } \\
\text { Meeting from the child's } \\
\text { school }\end{array}$ & Ironing \\
\hline & $\begin{array}{l}\text { Communication } \\
\text { with coworkers in } \\
\text { the factory }\end{array}$ & $\begin{array}{l}\text { Reading the Quran with } \\
\text { children }\end{array}$ & Cleaning the house \\
\hline
\end{tabular}

Source: Processed data (2021)

Copyright (C) 2021. Owned by Author(s), published by Society. This is an open-access article under the CC-BY-NC-SA license. 
The three cases of women public workers above show that public and domestic work is done alternately at home so that nothing is left out of the two because the two types of work are equally important. Public work informants who are lecturers work according to the schedule determined by the agency. Lecturer professions in the Tri Dharma of Higher Education such as education, research, and serving the community have been carried out at home. Domestic duties are taking care of children and taking care of the household. Domestic work taking care of children such as monitoring readiness to enter the online room, ensuring that you have joined the Zoom Meeting room or Google Classroom, meeting with class teachers about distance learning. Domestic duties take care of the household, such as going to the market, cleaning the house, cooking, preparing for family meals, and providing food stock.

Meanwhile, for women who work as batik entrepreneurs, jobs related to their fields, such as batik shops, are opened in a short time, opening from 10.00 am to 6.00 pm. Even so, batik sales are done not only offline but also online. In that way, additional goods remain income generation, shop assistants' finances, electricity payments' finances, and relationships with suppliers. Meanwhile, domestic tasks are taking care of children, such as providing two laptops for backup in case of difficulties due to signals, following the development of children reading the Koran, attending meetings with homeroom teachers. Domestic work takes care of the household, such as cooking for family meals, ironing clothes, cleaning the house, and going to the market.

During the pandemic, women who work as laborers do not work in the industrial sector. Even though the company does not pay the company at work, this informant gets income because he works from home. Labor Informants provide services such as cooking in restaurants and receiving laundry; these activities generate alternative income for their lives. Domestic work taking care of children, such as making sure the child has entered the Zoom Meeting or Google Classroom, following the development of reading the Quran and attending meetings with the homeroom teacher. Meanwhile, domestic work takes care of the household, such as cooking, ironing, and the market.

The three informants said domestic, and public work were two equally important jobs. Therefore, they said that the work could be done alternately. Domestic work was done in the morning, assisted by other family members such as husband and children. Meanwhile, public work is carried out after domestic work. Although public work is carried out regularly, domestic work does not interfere with public work. Therefore, during the COVID-19 pandemic, public and domestic work, women do two jobs at home without paying attention to one of the two jobs.

\subsection{Ownership of Facilities and Space and Social Activities}

Domestic space is identical with women's room because women do household and children's work every day, such as arranging space, cooking and arranging all household equipment, determining household facilities, and determining room arrangement. In that room, women have broad access to managing the house facilities, expressing themselves, and establishing relationships with other groups to form social activities in the COVID-19 pandemic, as shown in Table 2. These social activities were formed to help victims of viral pandemics and natural disasters during the COVID-19 pandemic. 
The Existence of Women's Roles during the COVID-19 Pandemic:

A Case Study of 3 Women in Yogyakarta

Table 2. Ownership of Women's Facilities, Space, and Social Activities

\begin{tabular}{|l|l|l|l|}
\hline \multicolumn{1}{|c|}{ Informant } & \multicolumn{1}{|c|}{ Facility } & \multicolumn{1}{|c|}{ Space } & \multicolumn{1}{c|}{ Social activity } \\
\hline Lecturer & $\begin{array}{l}\text { Internet } \\
\text { network, laptop, } \\
\text { cellphone }\end{array}$ & $\begin{array}{l}\text { Living room, } \\
\text { workroom, backroom, } \\
\text { living room }\end{array}$ & $\begin{array}{l}\text { The movers of the "Srikand" group } \\
\text { carried out social actions during the } \\
\text { COVID-19 pandemic and floods in } \\
\text { South Kalimantan }\end{array}$ \\
\hline Entrepreneur & $\begin{array}{l}\text { Internet } \\
\text { network, laptop, } \\
\text { cellphone }\end{array}$ & $\begin{array}{l}\text { Living room, living } \\
\text { room, family room, } \\
\text { upstairs }\end{array}$ & $\begin{array}{l}\text { Peduli" activists are engaged in } \\
\text { providing assistance to } \\
\text { underprivileged communities and } \\
\text { providing assistance to flood victims } \\
\text { in Central Kalimantan }\end{array}$ \\
\hline Laborer & Cellphone & $\begin{array}{l}\text { Family room, living } \\
\text { room, kitchen }\end{array}$ & $\begin{array}{l}\text { Engage in Friday alms, provide food } \\
\text { assistance to the surrounding } \\
\text { community }\end{array}$ \\
\hline
\end{tabular}

Source: Processed data (2021)

The Work from Home (WFH) policy provides space for women to have access to facilities, workspaces, and access to extensive relationships. The three informants have broad opportunities to use the necessary facilities according to their needs. Likewise, social actions can be carried out and assist disaster victims, such as assistance to communities affected by layoffs due to COVID-19. In addition, the social actions they do from home. They coordinate from their respective homes using virtual meetings. They are also connected with activists from within the country and abroad concerned with their care program. Broad access is access to facilities and space. Still, extensive relationships are evidence that at home and from home, women acclimatize themselves to the public sector at home and from home.

\subsection{Female Self-Existence}

COVID-19 has issued a policy to maintain distance so that Work From Home (WFH) is a policy the government has outlined in the Presidential Decree of the Republic of Indonesia No. 12 of 2020 on Stipulation Non-Natural Disasters of the Spread of COVID-19 as a National Disaster. Efforts to break the chain of transmission of COVID-19, which is transmitted by crowds, the Work From Home policy is simultaneously carried out in Indonesia. The "return" of workers to the home seems to impact women because women's existence improves positively. This can be seen from the ability of women to gain access to ownership of information from friends, colleagues, and family. In addition, women have established social relations to form social groups. These social activities contribute to victims of disasters such as viral disasters and natural disasters. Even though there is a duty to monitor school children, they also have broad access to establishing relationships with women who, in the end, are actively involved in a social organization. The existence of women starts at home, which produces various public activities that result in various self-actualizations, such as being part of an organization. They are housewives who can balance public and domestic activities.

Their involvement in the public world has been done because they are career women. However, the difference is that if they work in an office, if there is harassment against them, they do not dare to complain to their superiors or friends. They just kept quiet and let it happen for a long time. However, the three women said that violence did not occur when working from home. This is because using online media is much faster when they complain in the media. In

Copyright (C 2021. Owned by Author(s), published by Society. This is an open-access article under the CC-BY-NC-SA license. https://doi.org/10.33019/society.v9i2.326 
addition, the position at home is much stronger because beside them are husbands and children. Thus, women have never experienced violence while working from home.

The three informants admitted that it felt foreign to them when they worked from home because previously at home, they did domestic work. But over time, working from home is fun because they have mastered their home arena. They know all the intricacies of the arena long before they manage it. In connection with that, working from home becomes a fun thing for them. Feelings of pleasure and not being pressured have become part of them. From home, they have given birth to various relationships and high productivity to increase their existence even though they have become women who have careers but work in the era of the COVID-19 pandemic. Domestic space has brought the existence of women to the public sector.

\subsection{Theoretical Discussion}

In the era of the COVID-19 pandemic, there are Social Distancing and Physical Distancing policies to avoid crowds. This impacts Work From Home (WFH) to avoid crowds. Therefore, the work originally done outside the home and has its place is returned to the home, likewise with school children who originally studied in educational institutions, because the policy became a school from home. The house, which was originally a resting place for a family, has undergone a shift because the house is no longer a place to rest but a place of production where public work is carried out without leaving domestic work.

Women are the most affected by the Work From Home (WFH) policy. This is due to the stereotype of domestic women, where the domestic sector is a sector dominated by women. They have "power" over the arena of the house and everything in it, but so far, the work done in the house is domestic work. At COVID-19, the domestic sector was used by family members to carry out work from home and school from home for their children. Likewise, career women who work from home face domestic work and public work in the same place, namely at home. Both of these tasks are a double burden on women, which has been considered the cause of inequality. However, in the pandemic era, these two burdens are not a double burden but have proven that domestication has strengthened the existence of women. This is because the ability of women to manage the household and ownership of household access has led women to make it easier to carry out domestic and public tasks at home. These two tasks are not done alone, but various tasks with other family members; therefore, doing these two jobs does not add to women's burden. They can self-actualize from home by establishing relationships with outside parties and contributing to the community to help victims of COVID-19 and natural disasters. In addition, the violence that is concomitantly encountered in public sector work (Jacob et al., 2020), but when working from home, has never been experienced by women. In line with that, COVID-19 has shifted the stereotype of the domestication of women.

This study is in line with (Jacob et al., 2020; Sulistyawati et al., 2021), which states that women are not vulnerable to disaster conditions because women have managerial abilities in the domestic sector and women have a diligent and protective nature. In addition, women are resistant to disaster conditions because they are biologically stronger. Therefore, when COVID19, women are not vulnerable to this condition. Moreover, policies that require working from home, women can manage the household and protect family members so that household work, namely taking care of children husbands, and taking care of the household, can synergize with public work. Even from home, women can establish social relations both among social groups and with members outside the group through the media by holding meetings, seminars, and

Copyright (C) 2021. Owned by Author(s), published by Society. This is an open-access article under the CC-BY-NC-SA license. 
discussions to produce social actions from the social groups they form. In line with that, the existence of women is increasingly real in the era of COVID-19.

In line with that, the stereotype of women that women are only domestic, so they do not have a bargaining position which in the end women are weak, irrational, unable to manage their work, has become something that has happened in the COVID-19 era. Women have recognition because their ability to manage the household and their full power over household ownership has led them to achieve self-actualization that women can do domestic and public work from home.

COVID-19 has had a positive impact on the role of women in the stereotyping of women's domestics. Self-existence with various groups and managing households balance domestic and public work at home. Domestic work is done jointly with family members, after which career women focus on public work. Thus the two jobs are balanced. Accordingly, the domestic sector is the main place to generate public activities and form broad social relations.

\section{Conclusion}

The COVID-19 pandemic has erased the domestic stereotype of women. The Work From Home (WFH) policy has shown the role of women in carrying out their roles as housewives and career women. Both roles are carried out without having to leave one of them. Balancing the two tasks has been impossible, considering that career women have limited time, so it is not uncommon for women to be occupied in the domestic sector. However, the COVID-19 era has proven that career women can carry out both domestic and public tasks balanced. In addition, wider social relations are built from the domestic sector. Social groups are a tangible form in which women are leaders and have managerial roles in strengthening their existence and contributing to the wider community.

This research is limited to efforts to prove the existence of women in managing the household, which affects the relevance of the Work From Home (WFH) policy where women have access to both facilities and relationships in the home arena. Thus, the "return" of public work to home does not add to the burden on women but instead provides a strengthening of the existence of women in balancing domestic and public work from home. This also proves that the stereotype of women worthy of domestic work is closely related to gender construction. When women work outside the home, it will add to women's double burden. However, this has shifted that understanding. Thus, COVID-19 has strengthened the existence of women in the public sector. Further studies are needed regarding the post-COVID-19 position of women, whether the position of women working outside the home is still considered a double burden on women, resulting in gender inequality. This study is interesting for further research.

\section{Acknowledgment}

The authors would like to thank three informants who have provided detailed information about their activities during the pandemic used as material for this research.

\section{Declaration of Conflicting Interests}

The authors have declared no potential conflicts of interest concerning the study, authorship, and/or publication of this article. 


\section{References}

Casale, D., \& Posel, D. (2021). Gender Inequality and the COVID-19 Crisis: Evidence from a Large National Survey During South Africa's Lockdown. Research in Social Stratification and Mobility, 71(November 2020). https:/ / doi.org/10.1016/j.rssm.2020.100569

Chang, W. H. (2020). Understanding the COVID-19 Pandemic from a Gender Perspective. Taiwanese Journal of Obstetrics and Gynecology, 59(6), 801-807. https:/ / doi.org/10.1016/j.tjog.2020.09.004

Dewi, W. A. F. (2020). Dampak COVID-19 terhadap Implementasi Pembelajaran Daring di Sekolah Dasar. Edukatif: Jurnal Ilmu Pendidikan. https:/ / doi.org/10.31004/edukatif.v2i1.89

Fathoni, A. (2019). Dampak Covic 19 dan Kebijakan PSBB Pemerintah terhadap UMKM di Wiyung Surabaya. Dinar : Jurnal Prodi Ekonomi Syariah.

Hadiwardoyo, W. (2020). Kerugian Ekonomi Nasional Akibat Pandemi Covid-19. Baskara Journal of Business and Enterpreneurship.

Halaris, A. (2003). The detrimental effects of the COVID-19 pandemic on domestic violence against women. Journal of Psychiatric Research: Editorial. Journal of Psychiatric Research, 37(5), 355-356. https:/ / doi.org/10.1016/S0022-3956(03)00043-8

Hanoatubun, S. (2020). Dampak COVID-19 Terhadap Perekonomian Indonesia. Journal of Education, Psychology and Counseling.

Herdiana, D. (2020). Implementasi Kebijakan Pembatasan Sosial Berskala Besar (PSBB) sebagai Upaya Penanggulangan Corona Virus Disease 2019 (Covid-19). DECISION: Jurnal Administrasi Publik.

Hoang, V. M., Hoang, H. H., Khuong, Q. L., La, N. Q., \& Tran, T. T. H. (2020). Describing the pattern of the COVID-19 Epidemic in Vietnam. Global Health Action. https:/ / doi.org/10.1080/16549716.2020.1776526

Huang, C., Wang, Y., Li, X., Ren, L., Zhao, J., Hu, Y., ... Cao, B. (2020). Clinical Features of Patients Infected with 2019 Novel Coronavirus in Wuhan, China. The Lancet. https:/ / doi.org/10.1016/S0140-6736(20)30183-5

Jacob, C. M., Briana, D. D., Di Renzo, G. C., Modi, N., Bustreo, F., Conti, G., ... Hanson, M. (2020). Building Resilient Societies after COVID-19: the Case for Investing in Maternal, Neonatal, and Child Health. The Lancet Public Health, 5(11), e624-e627. https:/ / doi.org/10.1016/S2468-2667(20)30200-0

Jiang, P., Fu, X., Fan, Y. Van, Klemeš, J. J., Chen, P., Ma, S., \& Zhang, W. (2021). SpatialTemporal Potential Exposure Risk Analytics and Urban Sustainability Impacts Related to COVID-19 Mitigation: A Perspective from Car mobility Behaviour. Journal of Cleaner Production, 279. https:/ / doi.org/10.1016/j.jclepro.2020.123673

Khan, M. A., Vivek, Nabi, M. K., Khojah, M., \& Tahir, M. (2021). Students' Perception towards e-learning during Covid-19 Pandemic in India: An Empirical Study. Sustainability (Switzerland), 13(1), 1-14. https:/ / doi.org/10.3390/su13010057

Kristal, T., \& Yaish, M. (2020). Does the Coronavirus Pandemic Level the Gender Inequality Curve? (It doesn't). Research in Social Stratification and Mobility, 68(May), 0-4. https:/ / doi.org/10.1016/j.rssm.2020.100520

Leung, T. Y., Sharma, P., Adithipyangkul, P., \& Hosie, P. (2020). Gender equity and public health outcomes: The COVID-19 experience. Journal of Business Research, 116(May), 193-198. https:/ / doi.org/10.1016/j.jbusres.2020.05.031

Londoño, P. A., Nateras González, M. E., Bruno Solera, C., \& Paz, P. S. (2021). The Exacerbation of Violence Against Women as a form of Discrimination in the Period of the COVID-19 
Pandemic. Heliyon, 7(3). https:// doi.org/10.1016/j.heliyon.2021.e06491

Nasruddin, R., \& Haq, I. (2020). Pembatasan Sosial Berskala Besar (PSBB) dan Masyarakat Berpenghasilan Rendah. SALAM: Jurnal Sosial Dan Budaya Syar-I. https:// doi.org/10.15408/sjsbs.v7i7.15569

Nasution, D. A. D., Erlina, E., \& Muda, I. (2020). Dampak Pandemi COVID-19 terhadap Perekonomian Indonesia. Jurnal Benefita, 5(2), 212. https://doi.org/10.22216/jbe.v5i2.5313

Rahmadia, S., \& Febriyani, N. (2020). Dampak covid-19 terhadap ekonomi. Jurnal Ekonomi Islam(JE Islam).

Raj, A., Johns, N. E., Barker, K. M., \& Silverman, J. G. (2020). Time from COVID-19 Shutdown, Gender-based Violence Exposure, and Mental Health Outcomes among a State Representative Sample of California Residents. EClinicalMedicine, 26(March). https:/ / doi.org/10.1016/j.eclinm.2020.100520

Rana, I. A., Bhatti, S. S., Aslam, A. B., Jamshed, A., Ahmad, J., \& Shah, A. A. (2021). COVID-19 Risk Perception and Coping Mechanisms: Does Gender Make a Difference? International Journal of Disaster Risk Reduction, 55(February). https:/ / doi.org/10.1016/j.ijdrr.2021.102096

Ristyawati, A. (2020). Efektifitas Kebijakan Pembatasan Sosial Berskala Besar Dalam Masa Pandemi Corona Virus 2019 oleh Pemerintah Sesuai Amanat UUD NRI Tahun 1945. Administrative Law and Governance Journal. https:// doi.org/10.14710/alj.v3i2.240-249

Saputra, H., \& Salma, N. (2020). Dampak PSBB dan PSBB Transisi di DKI Jakarta dalam Pengendalian COVID-19. Media Kesehatan Masyarakat Indonesia. https:// doi.org/10.30597/mkmi.v16i3.11042.

Shammi, M., Bodrud-Doza, M., Towfiqul Islam, A. R. M., \& Rahman, M. M. (2020). COVID-19 pandemic, socioeconomic crisis and human stress in resource-limited settings: A case from Bangladesh. Heliyon, 6(5). https:// doi.org/10.1016/j.heliyon.2020.e04063

Shamseer, L., Bourgeault, I., Grunfeld, E., Moore, A., Peer, N., Straus, S. E., \& Tricco, A. C. (2021). Will COVID-19 result in a giant step backwards for women in academic science? Journal of Clinical Epidemiology, (xxxx). https://doi.org/10.1016/j.jclinepi.2021.03.004

Siahaan, M. (2020). Dampak Pandemi Covid-19 Terhadap Dunia Pendidikan. Jurnal Kajian Ilmiah. https:// doi.org/10.31599/jki.v1i1.265

Sulaeman, K. M., \& Salsabila, F. R. (2020). Dampak COVID-19 Terhadap Kaum Perempuan: $\begin{array}{llll}\text { Perspektif Feminisme. Jurnal Sentris, } & 1(2), & 159-172 .\end{array}$ https:/ / doi.org/10.26593/ sentris.v1i2.4283.159-172

Sulistyawati, S., Rokhmayanti, R., Aji, B., Wijayanti, S. P. M., Hastuti, S. K. W., Sukesi, T. W., \& Mulasari, S. A. (2021). Knowledge, attitudes, practices and information needs during the covid-19 pandemic in indonesia. Risk Management and Healthcare Policy, 14, 163-175. https:// doi.org/10.2147/RMHP.S288579

Susiana, S. (2020). Kekerasan Dalam Rumah Tangga pada Masa Pandemi Covid-19. Pusat Penelitian Badan Keahlian DPR RI, (12).

Syah, R. H. (2020). Dampak Covid-19 pada Pendidikan di Indonesia: Sekolah, Keterampilan, dan Proses Pembelajaran. SALAM: Jurnal Sosial Dan Budaya Syar-I. https://doi.org/10.15408/sjsbs.v7i5.15314

Wan, Y., Shang, J., Graham, R., Baric, R. S., \& Li, F. (2020). Receptor Recognition by the Novel Coronavirus from Wuhan: an Analysis Based on Decade-Long Structural Studies of SARS Coronavirus. Journal of Virology, 94(7). https:/ / doi.org/10.1128/jvi.00127-20

Yamali, F. R., \& Putri, R. N. (2020). Dampak Pandemi Covid-19 terhadap Ekonomi Indonesia. Ekonomis: Journal of Economics and Business. 
Zamberlan, A., Gioachin, F., \& Gritti, D. (2021). Work Less, Help Out More? The Persistence of Gender Inequality in Housework and Childcare during UK COVID-19. Research in Social Stratification and Mobility, (July 2020), 100583. https:// doi.org/10.1016/j.rssm.2021.100583

\section{About the Authors}

1. Napsiah obtained her Doctoral degree in Sociology from Universitas Padjadjaran, Indonesia, in 2015. The author is an Associate Professor at the Department of Sociology, Faculty of Social Sciences and Humanities, Universitas Islam Negeri Sunan Kalijaga.

E-Mail: napsiah@uin-suka.ac.id

2. Ahmad Norma Permata obtained his Doctor of Philosophy (PhD) from Westfälische Wilhelms Universität Münster, Germany, in 2008. The author is an Assistant Professor at the Department of Sociology, Faculty of Social Sciences and Humanities, Universitas Islam Negeri Sunan Kalijaga.

E-Mail: an.permata@uin-suka.ac.id

3. Dwi Nur Laela Fithriya obtained her Master's degree in International Relations from Universitas Gadjah Mada, Indonesia, in 2014. The author is an Assistant Professor at the Department of Sociology, Faculty of Social Sciences and Humanities, Universitas Islam Negeri Sunan Kalijaga.

E-Mail: fithriyadwi@gmail.com

4. Hikmalisa obtained her Master's degree in Interdisciplinary Islamic Studies from Universitas Islam Negeri Sunan Kalijaga, Indonesia, in 2019. The author is an Assistant Professor at the Department of Sociology, Faculty of Social Sciences and Humanities, Universitas Islam Negeri Sunan Kalijaga.

E-Mail: hikmalisa25@gmail.com 